\title{
Svarta(s) strategier: att hantera rasism och diskri- minering som svart svensk
}

\author{
VIKTORIJA KALONAITYTE, VICTORIA KAWESA \\ \& ADIAM TEDROS
}

Svarta svenskars upplevelser av diskriminering och rasism samt strategierna de nyttjar vid hanterandet av de upplevda kränkningarna ska avhandlas i följande artikel. De svarta svenskarnas motståndsstrategier är mångfacetterade och utmärks av såväl ett sökande efter trygga platser som ett konfrontativt agerande när de utsätts för rasism och diskriminering.

\section{Inledning}

Negativ särbehandling på basis av individens etniska bakgrund, föreställt etniskt ursprung eller fenotypiska drag är i dagens Sverige olaglig. Vidare är föreställningar om biologiskt grundade raser eller motsvarande ideologiska ståndpunkter idag bannlysta, inte minst på grund av raslärans ödesdigra historia i form av kolonialism, antisemitism

Viktorija Kalonaityte, fil.dr., forskare vid Företagsekonomiska institutionen, Lunds universitet Victoria Kawesa, doktorand vid Institutionen för Tema Genus, Linköpings universitet Adiam Tedros, fil.dr. i offentlig förvaltning vid Förvaltningshögskolan, Göteborgs universitet och apartheid. Även om rasbiologiska ideologier är idag misskrediterade, har ett växande antal forskare och debattörer påpekat att den samtida rasismen fortsätter att bidra till särskiljande, rangordning och utestängning utan en underliggande förankring i rasbiologin; för detta fenomen använder forskare istället begrepp som kulturrasism och etnisk rangordning (t.ex. Balibar \& Wallerstein 2002).

En uppsättning bidrag till kartläggningen av etnisk ojämlikhet i Sverige har belagt att det råder en samhällsekonomisk etnisk hierarki som skapas och legitimeras genom föreställningar om olika etniska gruppers kulturella särdrag. Utmärkande 
för denna hierarki är enligt dessa forskare att majoritetsbefolkningen hamnar högst upp, följd av de grupper av invandrare som tros vara kulturellt lika majoritetsbefolkningen. Dessa grupper utgörs av personer med bakgrund i vissa delar av västvärlden, t.ex. Norden, Tyskland, Storbritannien och USA. Rangordningen följer sedan ett mönster där asiater och afrikaners kulturella kapital anses vara mest bristfälligt (Andersson 2002, Dahlstedt \& Lindberg 2002, de los Reyes et al. 2002). Konsekvenserna av positionen i den etniska maktordningen är flera; de grupper som befinner sig längst ner i den etniska hierarkin har lägre disponibel inkomst, en högre arbetslöshet, lägre grad av politiskt deltagande samt bor oftare i resurssvaga områden (Andersson 2002, Blomqvist 2005, Dahlstedt \& Lindberg 2002, Neergaard 2002).

Statistiska studier visar på den etniska hierarkin som ett övergripande samhälligt mönster, baserat på individers och/ eller föräldrars ursprungsländer. Det som däremot inte framgår av dessa studier är hur dessa mönster skapas genom vardagliga handlingar och incidenter. Vi vill också framhålla att forskning om vardagsaspekten av diskriminering och rasism bör ta hänsyn inte bara till gruppens position inom den etniska rangordningen, utan också till föreställningar kring den studerade etniska gruppens kulturella egenskaper, då dessa föreställningar skiljer sig markant, även om de mest utsatta grupperna med rötter i Asien och Afrika (jfr. Prasad 2005). Dessutom kan inte analyser av de övergripande mönstren baserade på nationalitet på ett uttömmande sätt ta fasta på diskrimineringen av personer som i flera generationer har bott i diasporasamhällen utanför den afrikanska kontinent deras fenotypiska drag förknippas med. Trots dessa insikter är riktade studier mot rasifierade grupper sällsynta. Vidare lyser studier som tar ett helhetsgrepp på svarta svenskars erfarenheter av rasism och diskriminering med sin frånvaro. Några försök har dock gjorts; Ulrika Schmauch, som i sin avhandling "Den osynliga vardagsrasismens realitet " (2006) belyser hur unga personer med bakgrund i Afrika hanterar rasism, kan här framhållas. Viveca Motsieloas (2003) studie »Det måste vara något annat « om unga svarta svenskars erfarenhet av rasism och diskriminering är ett annat viktigt bidrag till fältet. De två ovan nämnda studierna tecknar en nedslående bild av svarta svenskars situation. Såväl Schmauch som Motsieloa framhåller i sina studier hur majoritetssamhället osynliggör erfarenheterna av rasism och diskriminering som de svarta ungdomarna ger uttryck för. Det saknas också forskning om de specifika former av rasism och diskriminering som riktas mot hela den svarta gruppen och inte uteslutande den yngre populationen.

Vårt övergripande syfte med den studie vi här presenterar är att utröna hur svarta svenskar upplever diskrimineringens och rasismens närvaro och effekter i sin vardag. Utsätts de för diskriminering och rasism och i så fall vilka specifika typer av kränkningar? Genom att fokusera på gruppen svarta svenskar är vår förhoppning att fånga det partikulära i diskriminering och rasism riktade mot just den gruppen. Vi vill utöver att synliggöra deras erfarenheter av diskriminering och rasism även ta fasta på deras strategier att hantera olika incidenter i var- 
dagen. Härigenom kan vi visa på samspelet mellan inskränkande sociala strukturer och föreställningar och svarta svenskars aktörskap och möjligheter att i viss mån påverka sin situation inom ramen för dessa begränsningar. Dessa syften innebär att vår primära uppgift är att sätta de intervjuades berättelser i centrum och genom en tolkande ansats identifiera och presentera de upplevelser som är såväl återkommande som spridda.

\section{Teoretiskt perspektiv}

Vår övergripande teoretiska position är att rasism och etnisk diskriminering som fenomen har sin grund i en rasistisk diskurs, dvs. en underliggande samling systematiserade föreställningar om fenotyper, karaktärsdrag och makthierarkier mellan dessa (se t.ex. Van Dijk 1993). Rasism som diskurs skapar och vidmakthåller föreställningar om att hudfärg och vissa fenotypiska drag är kopplade till karaktärsdrag, grad av kultivering och intellektuell utveckling samt till kulturell och nationell tillhörighet (Young 1995). Rasismens uttryckssätt är mångfacetterade och i enlighet med Prasad (2005) menar vi att man bör tala om olika rasistiska diskurser, såsom orientalism (gäller Asien och Mellanöstern), tropikalisering (gäller Latinamerika) samt primitivism (gäller Afrika). I samma anda anser vi att diskriminering och rasism behöver studeras utifrån det s.k. intersektionella perspektivet (de los Reyes \& Mulinari 2005, Lykke 2005). Centralt i detta är att flera strukturella differentieringsgrunder ses som viktiga att inkludera i analysen. I vårt fall har vi valt att titta på genusdimensionen i upplevelser av rasism och diskriminering bland personer med afrikansk bakgrund.

Det som är väsentligt att lyfta fram är att en diskurs strukturerar sättet att tala, tänka och handla i relation till den specifika stereotypen, i detta fall ett föreställt afrikanskt ursprung, och definierar vad som är normalt, accepterat och rätt att säga och tycka. Vetenskapliga teorier baserade på rasbiologi har visserligen avvecklats, men istället har nya doktriner om etniska och fenotypiska hierarkier trätt fram, såsom teorier om kultur och kulturell särart, eller teorier om utveckling och underutveckling. Ett diskursperspektiv innebär också att diskurser förankras, artikuleras och sprids via olika samhällsinstitutioner och får således materiella effekter. Slutligen styr diskursen fördelningen av handlingsutrymmet hos alla berörda parter och är relationell - positionen "svart" skapas och framhävs i relation till gjorda anspråk på »vithetw. Young (1995 s. 166) citerar Trotter som hävdar att den koloniala diskursen kan betraktas som en text utan författare - dvs. att referensramen, ojämlika maktrelationer, ojämlik fördelning av handlingsutrymmet samt institutioner som upprätthåller dessa finns tillgängliga. Det krävs med andra ord inget aktivt samtycke för att delta i diskursen, utan snarare aktivt motstånd för att sluta delta.

Det som är av teoretiskt intresse för oss är svarta svenskars upplevelser av rasism och diskriminering. Diskurssynsättet ger oss det övergripande perspektivet, dvs. förklaringsramen för olika former av särbehandling baserad på fenotyp och föreställd etnisk och kulturell bakgrund. Det vi vill undersöka är i vilken mån och hur den rasis- 
tiska diskursen som strukturerar negativa föreställningar om afrikaner präglar svarta svenskars liv. Vi avser således att undersöka diskrimineringens och rasismens subjektiva, dvs. upplevelsebaserade dimension, i kontrast till statistiska kartläggningar av diskriminering som kan betraktas som objektiva mätningar av etnisk ojämlikhet i Sverige. Vi vill också se på de strategier som svarta svenskar använder sig av för att bemöta den negativa särbehandlingen, dvs. hur de utövar motstånd eller försöker påverka de dominerande diskursiva strukturerna om deras föreställda kulturella och etniska arv.

De begrepp som vi anser vara värdefulla i vår studie är diskriminering och vardagsrasism. Dessa är besläktade på så sätt att de förutsätter en maktrelation mellan den som diskriminerar alternativt utsätter någon för en rasistisk handling och den som blir offer för någon av dessa handlingar. Begreppet diskriminering är dock inriktat på utfallet av en orättvisa eller den negativa särbehandlingen, ofta ett socioekonomiskt sådant (t.ex. utebliven anställning). Diskriminering är därtill ett vidare begrepp då den kan ske på en mängd olika grunder, såsom kön, etnicitet, hudfärg, religion, sexuell läggning eller ålder. Analytiskt innebär diskrimineringsbegreppet sökandet efter teman i de intervjuades utsagor som tyder på att de intervjuade har upplevt särbehandling med negativt utfall med etniska förtecken, men utan explicita referenser till exempelvis Afrika eller svart hudfärg.

Begreppet rasism kan, med utgångspunkt $i$ vår teoretiska referensram, ses som ett paraplybegrepp för såväl olika former av negativ särbehandling baserad på rasistiska diskurser som den negativa särbehandlingens utfall. Vi använder oss av ett mer preciserat begrepp som utvecklats av Philomena Essed (1991), nämligen vardagsrasism. Det fokuserar på vardagliga skeenden och deras mönster och kumulativa effekter på individer som utsätts för dem. Vi menar att det begreppet äger större giltighet $i$ vår studie då det inkluderar både informella och offentliga sociala sammanhang, ojämlika och förnedrande villkor, rasismens psykosociala effekter samt språkliga och interaktionsbaserade kränkningar (Essed 1991). Analytiskt omfattar begreppet vardagsrasism fenomen som inte nödvändigtvis leder till omedelbara socioekonomiska effekter, exempelvis kränkande språkbruk på offentliga platser eller exotisering av svarta kvinnors utseende.

Sammanfattningsvis ger det individperspektiv som vi använder oss av möjlighet att studera upplevelser av negativ särbehandling och vardagsrasism riktad mot en specifik grupp samt gruppens motståndsstrategier. Med andra ord: i den mån dominerande diskurser skapar sociala strukturer som begränsar och ibland hindar individer, kan individer ses som utövare av motstånd, och sådant individuellt motstånd bör betraktas som en del av en mer omfattande formulering av motdiskurser.

\section{Studiens material och tillvägagångssätt}

Vårt material består av sammanlagt 60 intervjuer med personer som identifierar sig själva som svarta svenskar i åldrarna 15-65 år, bosatta i någon av Sveriges tre 
största städer, Göteborg, Malmö och Stockholm. ${ }^{1}$ Urval och identifiering av personer "med afrikansk bakgrund» kräver en mer ingående diskussion då begreppet inte är helt oproblematisk ur urvalssynpunkt. Det finns 118214 personer med afrikansk bakgrund i Sverige (SCB 2007), dvs. som antingen själva är födda i Afrika eller vilkas båda föräldrar är utrikesfödda varav åtminstone en är född i Afrika. Vi har i huvudsak intervjuat personer som i den officiella statistiken ingår i kategorin "person med afrikansk bakgrund", men vi har även inkluderat andra. Den gemensamma nämnaren bland dem vi intervjuat är att hudfärgen nyttjas som en markör för härkomst och gemensamt för dem är således att de upplever att de identifieras som svarta afrikaner av sin omgivning, oavsett i vilken kategori de hamnar enligt den officiella definitionen. Vi har kommit i kontakt med intervjupersonerna genom de olika afrikanska föreningar som finns $i$ våra tre storstäder. Efter en första kontakt med enskilda personer från föreningarna har vi bett dem att förmedla kontakt med andra personer inom deras nätverk. Studien bygger på semistrukturerade intervjuer och fokusgruppssamtal. De intervjuade fick prata relativt fritt kring de teman som redovisats i syftet, "erfarenheter" och "strategier". De hade möjlighet att själva bestämma formen för intervjun; vissa föredrog att intervjuas tillsammans med en eller flera vänner med afrikansk bakgrund, medan andra föredrog att samtala enskilt

1 Intervjuerna är genomförda inom ramen för två olika delstudier, en om vuxna och en om ungdomar gjorda på uppdrag av Ombudsman mot etnisk diskriminering. med intervjuaren. Två fokusgruppsintervjuer organiserades med sammanlagt sju män och sju kvinnor. De resterande intervjuerna har genomförts individuellt. Varje intervju varade mellan en och två timmar, spelades in och transkriberades senare ordagrant för analysen.

Studiens syfte återspeglas i frågeformulären, men vi ställde inga ledande frågor, och vi krävde inte heller svar på frågor som intervjupersonerna inte ville besvara. I vårt urval har vi eftersträvat en jämn könsfördelning samt en spridning inom den valda ålderskategorin. Avseende ursprungets geografiska spridning har vi eftersträvat att inkludera personer med rötter från vad som kallas för Afrika söder om Sahara. Vi har intervjuat personer med rötter i Västafrika, Östafrika samt Södra Afrika.

De 60 personer som vi har intervjuat har tillhandahållit ett gediget kvalitativt material. Det innehåller variation, i form av bakgrund och livsvillkor, samtidigt som det innehåller ett antal teman som är återkommande, som vi redovisar och analyserar nedan.

\section{Empirisk diskussion: svarta(s) strategier}

Vår empiriska analys av svarta svenskars upplevelser av rasism och diskriminering bygger på två övergripande teman; det första är upplevda kränkningar och det andra är strategier som de intervjuade individerna använder sig av för att bemöta diskriminerande behandling.

Alla intervjuade ansåg att de hade erfarenheter av rasism och/eller diskriminering; vi har således inte stött på någon som inte 
ansåg sig ha upplevt detta. Våra resultat tyder vidare på att gruppen svarta svenskar har specifika upplevelser som kan grupperas i olika typer. Gruppen svarta svenskar utsätts för kränkande behandling, baserad på specifika referenser till deras hudfärg, fenotyp och nedsättande Afrikametaforer. Dessa kränkningar har vidare visat sig samspela med genusstereotyper; kvinnliga informanter har ofta upplevt sexuella trakasserier, baserade på föreställningar om Afrikanska kvinnor som sexuellt tillgängliga eller översexualiserade. Manliga informanter har oftare upplevt att de misstänkliggörs av polisen och väktare.

Kränkningar, specifika för gruppen svarta svenskar, kan vålla vitt skilda konsekvenser beroende på den sociala kontexten inom vilken de sker. Vi har använt oss av begreppet institution för att fånga hur våra intervjupersoner upplever diskriminering inom olika sociala arenor, såsom skolan, arbetslivet eller det offentliga rummet. Förståelsen för hur vardagsrasism och diskriminering upplevs inom olika institutioner ger oss möjlighet att se hur kränkningar kan leda till långvariga konsekvenser genom att de sker inom relationer med maktasymmetrier, t.ex. lärare - elev. Samtidigt är det viktigt att ha i åtanke att negativ särbehandling som sker inom institutioner såsom arbetslivet inte alltid behöver innebära att den diskriminerade personen får en explicit förklaring av den missgynnande behandlingen. Fokus på institutioner ger oss dessutom möjlighet att belysa hur diskriminering upplevs av ungdomar respektive vuxna på relevanta sociala arenor, något som kräver olika typer av sociala resurser och åtgärder för att stoppas och förebyggas.

\section{Typer av kränkningar}

\section{Kränkande språkbruk}

De intervjuade svarta svenskarna har genomgående upplevt ett kränkande språkbruk riktas mot dem, i det offentliga rummet, i skolan eller på arbetsplatsen. Kränkande språkbruk kännetecknas av riktade anmärkningar som anspelar på svart hudfärg och fenotyp, nedsättande uttalanden om Afrika samt metaforer och uttalanden om afrikaners primitivism eller underutveckling. För många yngre informanter, födda i Sverige, kommer erfarenheterna av ett rasistiskt språkbruk tidigt, i möten med andra barn på dagis eller på lekplatsen. Ett representativt exempel på nedsättande språkbruk riktat mot svarta svenskar är skällsord av rasbiologiskt ursprung, som exempelvis i Pauls, 32 år, berättelse om sitt första minne av att behandlas rasistiskt:

Mitt första minne av diskriminering var när jag var fyra år. Jag blev uppjagad på ett tak, jag fick inte leka med de andra barnen. Det var på ett privat dagis, och jag kommer ihåg att det var någon som skrek vad fan gör du här djävla neger. Och han hade en hund, den skulle attackera mig, han släppte den där hunden mot mig, jag hade hundfobi flera år efteråt.

Ett annat exempel kommer från Stephen, 16 år, som berättar hur nedsättande kommentarer, som bygger på föreställningar om svartas primitivism, kan fällas i klassrummet utan intervention från lärare: 
Det kan vara en apa, och då säger någon, kolla apa, är inte det du? En kompis till mig... det var $i$ en bok, och det var en apa, och någon i klassen sa till honom, 'är inte det där du när du var liten'?

De språkliga kränkningarnas omfattning och konsekvenser varierar. För flertalet yngre svarta svenskar präglades skolgången av mobbning på rasistiska grunder, särskilt i skolmiljöer som i övrigt kännetecknades av frånvaro av etnisk mångfald. Äldre svarta svenskar, som har migrerat till Sverige i vuxen ålder, förknippar ofta erfarenheter av rasistiskt språkbruk med arbetslivet. Eliza, 40 år, berättar om sin första upplevelse av kränkande språkbruk som anställd i ett ungdomsprojekt:

En annan gång var det några elever som skulle donera datorer till Tanzania. Och så gick jag förbi och hörde 'var ska de sätta kontakten, i trädstammen?'. Det som gjorde mig arg var att rektorn och de andra skrattade. Jag gick bara upp till biblioteket, och då kom rektorn springande efter mig och sa att 'vi känner till så lite om Afrika'. Då sa jag att det handlar om att det var så fördomsfullt sagt. Sen bad hon om ursäkt.

Föreställningar om att personer med afrikansk bakgrund är underlägsna, särskilt när dessa föreställningar flätas samman med utbildnings- eller anställningspraktiker, kan leda till långsiktiga sociala och ekonomiska konsekvenser för de diskriminerade individerna. Vid mötet med Sverige berättar flera av dem vi har intervjuat att det har funnits tydliga föreställningar om att de som afrikaner har en bristande förmåga att till- skansa sig en utbildning, som till exempel i Sofias, 32 år, fall:

Jag ville antingen läsa något samhällsvetenskapligt eller något av de naturvetenskapliga ämnena, det var vad jag var intresserad av. Men de sa det rakt ut, 'du har inte förmågan' till mig och till några av mina kompisar, som också var afrikaner, de sa att det är inte samma utbildningar som ni har där nere.

Även de svarta svenskarnas försök att tillskansa sig en högre position på arbetsplatsen har stött på motstånd. En av dem vi har intervjuat utrycker det som att "jag växte för snabbt för en afrikan". En annan, Cindy, 39 år, berättar om hur det var att vara svart på sin arbetsplats:

Mitt första jobb som administratör, där började folk fråga mig, 'hur hamnade du här?' Det var som att en svart människa inte kunde ha det jobbet. Min chef sa till mig att när hon växte upp hade hon inte kontakt med svarta människor. Man kände att det fanns en mur mellan 'oss' och 'dem'.

Den institutionella dimensionen av språkliga kränkningar och negativa föreställningar om afrikansk bakgrund indikerar att svarta svenskar upplever att deras intellektuella och sociala kapital bedöms som underlägset och bristfälligt och vid ett senare tillfälle kan användas för att legitimera negativ särbehandling i arbetslivet och utbildningssammanhang. 


\section{Integritetskränkningar}

De typer av kränkningar som är specifika för gruppen svarta svenskar inbegriper även integritetskränkningar, dvs. att den annars respekterade integritetsgränsen, såsom att inte vidröra en person utan tillåtelse, inte respekteras. Integritetskränkningar rättfärdigas med referens till svarta svenskars afrikanska bakgrund, annorlunda hudfärg eller hår. Sara, 15 år, berättar att det var vanligt att hennes utseende kommenterandes i skolan när hon var yngre:

På mellanstadiet var det mycket sånt, typ 'kolla på henne. Kan du duscha, och när du duschar, faller färgen av, kan du tvätta håret, blir ditt hår blött när du tvättar det, kan du kamma håret?' Det var mycket sånt där.

Integritetskränkningar sker i skolan, på arbetsplatsen eller i det offentliga rummet, och kan präglas av exotisering, som i Saras exempel ovan, men också av öppna trakasserier. Ett exempel är när Jonas, 40 år, blev kränkt av sin chef:

Det var ett möte med olika personer som arbetar med ungdomsfrågor. Sen hände en annan sak, då hade jag jobbat där i fem, sex veckor. Då kom en kollega fram och skulle hälsa och vi kramades, och då sa min chef, vad är det här för särbehandling, är det bara Jonas som fär en kram? Då gick han ned och tog smuts från marken och lade det $i$ sitt ansikte, och då sa han 'nu är jag också svart, nu vill jag också ha en kram'.

Ett exempel på trakasserande behandling är Sofias, 32 år, erfarenhet när en patient tar sig friheten att gå över gränsen för den personliga integriteten:

Jag upplevde det som verkligt kränkande när en patient klappade mig på rumpan och sa 'jag vill känna på en afrikansk rumpa'.

Integritetskränkningar inbegriper, som exemplen ovan visar, såväl exotiserande som nedsättande kränkningar. Det finns dock anledning att inte trivialisera de till synes oskyldiga och nyfikenhetsbaserade försök att känna på personens hår eller hud, då de tyder på att respekten för den personliga integriteten som annars är vägledande i interaktionen mellan människor överskrids ifråga om svarta svenskar. Integritetskränkande trakasserier som i exemplet ovan kan vidare ha en ännu tydligare sexualiserande dimension som vi undersöker närmare i avsnittet nedan.

\section{Sexuella trakasserier}

Många av de kvinnliga informanterna berättar att de ofta utsätts för sexuella trakasserier med en rasifierad prägel. Claudia, 45 år, berättar hur hennes yrkesliv har präglas av sexuella anspelningar från hennes kunder:

Sexuella trakasserier upplever jag hela tiden, även idag. När jag jobbade med att anordna olika events, även om det var ett seriöst yrke, när man beställde en tjänst av mig fanns det en förväntan frän beställaren att jag ingick i det. Jag har till och med tillfrägats hur mycket jag skulle ta om det var 'hela paketet'. Och ibland så kunde det vara 
'kan du ordna några afrikanska tjejer' och det rör sig om myndighetspersoner. När jag har ordnat temakvällar så har jag tillfrägats om jag kan ordna några tjejer som kan närvara. Det har jag upplevt som oerhört kränkande, det förekom väldigt ofta.

Sexuella trakasserier kan förekomma i det offentliga rummet och tyder på att den fria rörligheten är begränsad för vissa grupper medborgare i vårt samhälle. Anna, 28 år, menar på att hon upplever att hon blir behandlad som om hon vore en kvinna till salu när hon rör sig i det offentliga rummet:

Jag går på gatan här och väntar på bussen, så kommer män i bilar som stannar och frågar om jag vill hänga med. När jag var ute sist och väntade på bussen kom två snubbar och sa 'vi kan köra dig, ska du hänga med', jag svarade 'jag vill inte', och då sa de 'om du vill så väntar vi på dig'. Så fort de ser en svart kvinna så tror de att hon är en prostituerad.

Flera av våra kvinnliga informanter berättade om sina erfarenheter av att utsättas för sexuella anspelningar av män på offentliga platser som busshållplatser och affärer. I likhet med Claudias upplevelse om att kunder inte respekterande hennes yrkesroll och använde sig av rasifierade sexualiserade antydningar, hade ett flertal av kvinnorna upplevt förfrågningar om sexuella tjänster eller berättelser om sexuella kontakter med afrikanska kvinnor, som kunde komma från män i deras bekantskapskrets eller till och med lärare.

\section{Misstänkliggörande}

Om kvinnornas erfarenheter är att integritetskränkningar tenderar att få en sexualiserad dimension, upplever de intervjuade männen ofta att deras fria rörlighet i det offentliga rummet inskränks genom spontana poliskontroller eller misstänkliggörande utan en substantiell bas; stereotypa föreställningar om svarta män som potentiella brottslingar verkar prägla de intervjuades erfarenheter av att bli stoppade och förhörda i det offentliga rummet. Abdul, 16 år, menar på att det är relativt vanligt enligt hans erfarenhet att misstänkliggöras av polisen och behöva utsättas för förnedrande behandling i samband med kroppsvisitering:

En gång när vi hade spelat basket hade jag en stor väska. Vi stannade till vid McDonald's och jag gick till bankomaten. Där stoppade polisen mig och tullade mig och kollade igenom min väska. Sen tar de ut min basketboll och frägar mig, vad har du där inne? Jag svarade 'ingenting', det är ju bara luft. Och så skakade de bollen. Och sen frägade de vems bankomatkort det var jag skulle ta ut pengar med. En annan gång när de stannade mig sa de att 'en kille som har blivit beskriven som du har ränat en gammal tants väska'. Sen en annan gång så stannade de mig för att det hade varit rån på 7-eleven.

Andra vanliga erfarenheter våra informanter berättar om är att stoppas av butiksvakter och misstänkliggöras som potentiella snattare, att få legitimera sig som passagerare i en bil, att ifrågasättas när man går in 
i byggnader eller ett fordon som förknippas med hög social status.

\section{Hatbrott}

Några av våra intervjupersoner har erfarit rasistiskt våld, som också kan benämnas som hatbrott. Peter, 31 år, berättar om sin arbetsplats, en skola, där han, tillsammans med en svart kollega, blir slagen upprepade gånger av en elev som tillhör en grupp studerande som öppet talar om "vit maktu:

I mitt fall var det en stökig elev som hade skolkat, han var stökig och ville hänga vid receptionen, och jag sa till honom att sluta. Han hade fötterna på bordet, han rev ur katalogen och man försökte säga till, men han vägrade. Han slår till en elev, och jag säger till honom, 'nu fär det vara nog, nu är du dessutom på receptionsområdet, där $d u$ inte fär vara'. Han vägrar, jag tar tag $i$ honom, och han spjärnar emot. När jag lyckas få ut honom frän receptionsomradet, då släpper jag honom, och han tar och slänger en penna rakt $i$ ansiktet mot mig. Då tar jag tag i honom på ryggen och säger 'nu räcker det, nu följer du med till rektorn'. Han vägrar, då tar jag tag $i$ honom i båda axlarna, och säger igen, 'nu följer du med till rektorn'. Det blir tumult och han lyckas ta sig lös, och då fär han in en rak höger mot mitt öga. Jag släpper honom helt chockad och säger till honom, 'va slog du migjust nu?' då säger han 'vad ska du göra mot mig?' Jag försöker få iväg honom igen till rektorn, men märker när vi kommer till en dörröppning att det inte kommer gå, han sprattlar med armar och ben och jag släpper honom. Dà skriker han 'djävla neger', och allt möjligt och springer iväg.

Peters berättelse ovan belyser den första incidenten där han blir slagen av en elev. Samma elev slår Peter igen, samt en annan svart lärare på samma skola. Skolans ledning valde dock, enligt Peter, att inte polisanmäla incidenten och tysta ner förekomsten av rasistiskt våld på skolan. Peters berättelse illustrerar det som andra intervjupersoner också bekräftar, att rasistiskt våld och hatbrott inte behöver utföras av okända våldsmän i oskyddade miljöer. Dessutom anmäls dessa brott sällan av ansvariga parter.

\section{Strategier}

De strategier som våra intervjupersoner delger oss är av varierande slag. Det rör sig om såväl direkta som indirekta strategier, dvs. sådana som används vid den instansen kränkningen sker, respektive strategier av en mer övergripande art. Utmärkande för båda typerna är dock att de är ofrivilliga till sin natur, dvs. de många kränkningar som de svarta svenskarna utsätts för tvingar fram en rad olika ageranden. Bland de vuxna som vi har intervjuat ger flera uttryck för en viss förvåning över att utsättas för rasism och diskriminering i Sverige. Jonas, 40 år, med ursprung i Sydafrika uttrycker det som följer:

Jag var politiskt aktiv i Sydafrika, mot apartheid, och så tänkte jag, ska jag behöva börja om från början igen? Jag har kämpat för att 
inte vara en andra klassens medborgare, och nu var jag det igen. Det kändes bara, hur ska man göra?

Jonas och flera av dem vi har intervjuat gör dock motstånd mot vad de upplever som diskriminering och rasism. Linda, 17 år, är ytterligare en person som redovisat hur hon gör motstånd rent konkret. Hon berättar hur hon står på sig i ett samtal med rektorn på hennes skola om vad som är ett acceptabelt språkbruk:

Det var en kille i min skola som sa 'neger' och då sa jag till honom att 'du vet att jag kan anmäla dig?' och då blev han lite skraj. Jag gick till rektorn och berättade vad som hade hänt och då sa rektorn: 'när jag var lika ung som du var det ok att säga neger'. Och då sa jag till henne att det handlade om vad som hade hänt mig nu, och inte vad som hände för 30 år sen. Jag kände bara att kan hon fokusera på vad som hade hänt mig? [...] Sen sa hon: 'du kommer allid att vara svart, och du kommer att bli bemött så här hela ditt liv'. Då sa jag 'när jag går till skolan, ICA eller över gatan då kommer jag inte att bli bemött så här. Ingen säger neger. Varför ska du säga till mig hur jag ska bli behandlad när du inte ens kan ta tag i det'. Jag tänkte vem är du att säga till mig hur mitt liv kommer att se ut och hur jag kommer att behandlas. Du kan inte ens säga till killen som kränkte mig.

Det som är kännetecknande för de strategier som våra intervjupersoner använder sig av är att de, som i Jonas fall, växer fram ur konkreta situationer som strider mot föreställningen om Sverige som ett rättvist och jämlikt land. Vidare kräver strategierna, såsom anmälningen i Lindas berättelse, att berörda auktoritetspersoner och myndigheter stödjer individen och vidtar lämpliga åtgärder, något som de ofta underlåter att göra när det gäller svarta svenskar. Avsaknad av förståelse för diskriminering som specifikt drabbar svarta är en förklaring som intervjupersonerna använder sig av för att begripliggöra bristande stöd från myndigheter, såsom i den första strategin, trygghets- och representativitetsskapande, som vi redovisar nedan.

\section{Skapa trygga platser och kräva representativitet}

En första strategi som vi har identifierat handlar om att hitta alternativt skapa platser där man som svart svensk kan känna sig trygg. David, 31 år, menar i likhet med flera andra vi har intervjuat, att det finns en geografisk dimension:

De tre storstäderna, där skulle jag bosätta mig. Inte i en mindre stad i Sverige. [...] Man får utstå en massa skit i småhålor.

Den geografiska uppdelningen av städer i trygga och otrygga platser sker på grundval av större etnisk mångfald, och närvaro av flera svarta i storstäderna. Utöver strategin att bosätta sig i städer med en högre andel svarta ger såväl de yngre som de äldre vi har intervjuat uttryck för strategin att omge sig med andra svarta. Medan de äldre vanligen gör det i mer organiserad form, de söker sig till olika föreningar, kan det för de yngre handla om att söka sig till de svarta eleverna 
i klassen alternativt skolan, något Carolina och Alexandra, båda 18 år, berättar för oss:

Vi som umgås är sex svarta tjejer och det är 30 i klassen och alla umgås i grupper.

Vi kan ovan se att Caroline och Alexandra ger uttryck för att deras strategi, enligt deras mening, på intet sätt är ovanlig. Däremot är de mer synliggjorda som svarta svenskar när de väljer att umgås med andra svarta elever. Strategin att söka sig till miljöer som är representativa för svarta svenskars erfarenheter och således troligen mer stödjande när det gäller erfarenheter av diskriminering och rasism, lämnar avtryck på de intervjuades förhållningssätt till deras barn, vilket nästa avsnitt indikerar.

\section{Förbereda eller skyddabarnen?}

Flera av dem vi har intervjuat har berättat att de har tagit sina barn ur den kommunala skolan och satt dem i skolor som signalerar en annan värdegrund eller ökade möjligheter att hävda sig utbildnings- och yrkesmässigt. Mark, 35 år, vars barn går i ett engelskspråkigt dagis menar att det finns flera skäl till varför han och hans fru har valt att agera på det sättet:

De måste vara stolta över vem de är, så de har tre afrikanska namn, min dotter har fyra namn. Och jag har lärt dem mitt språk. Även om min släkt kan engelska så är mitt språk jätteviktigt för dem. Jag vill att de ska känna att det är viktigt för dem, och också för att de aldrig kommer att accepteras helt som svenskar.
Marks beslut kan ses som ett val att ge sina barn möjlighet att i framtiden välja om de vill bo kvar i Sverige, eller flytta antingen till hemlandet eller till ett engelskspråkigt land. Diana, 50 år, har valt en motsatt strategi, istället för att sätta barnen i en privatskola har hon istället valt att låta barnen gå kvar i den kommunala skolan och på så sätt stifta bekantskap med hur det verkligen ser ut i samhället:

Mina barn blev mobbade i skolan och jag blev tvungen att sitta med $i$ skolan för att bevaka. Ett tag funderade jag på att skicka dem till en diplomatskola för att de skulle slippa det, men jag fick rådet frän en landsman som var lektor att det var bättre att de fick möta samhället som det verkligen såg ut. Men det var tufft många gånger, en gång hade de målat BSS på vårt hus och jag visste inte vad det betydde, 'Bevara Sverige Svenskt' berättade mina barn för mig.

Tanya, 42 år, berättar om hur hon blev tvungen att skicka sin son att studera i Sydafrika för att lärarna i den svenska skolan tyckte att hon som förälder inte skulle hjälpa honom med läxorna hemma eftersom han var för duktig. Det var då hon och hennes man bestämde sig för att ta honom från Sverige och skicka honom till en skola i Sydafrika där han skulle kunna få utvecklas på sina egna villkor. Strategierna må se olika ut, men det är samma problematik - diskriminering, nuvarande såväl som framtida, som svarta föräldrar försöker lösa genom medvetna skolval och extra engagemang.

Vi kan urskilja två olika strategier när det gäller hur diskussionerna om rasism förs $i$ hemmen. Å ena sidan har vi de som menar 
att det är viktigt att berätta om rasismen i samhället och på så sätt skydda barnen och å andra sidan finns det de som menar att det kan finnas problem med att själv introducera ämnet för barnen. Ahmed, 32 år, berättar att han pratar om rasism och diskriminering med sina barn för att förbereda dem inför framtida händelser:

Jag tror att man måste berätta för dem att livet inte är rättvist. Ge dem den nödvändiga informationen, säga sanningen helt enkelt. Gör man det från början ökar chanserna att de kommer att lyckas.

Olga, 40 år, berättar att i hennes familj pratar de inte om rasism förrän det händer, eftersom hon ogärna vill att andras erfarenheter ska få företräde före barnens egna:

I min familj bestämde vi att mina barn ska ha vårt språk. Sen tycker jag att barnen ska besöka hemlandet, och ha koppling till släktingar. Föräldrar ska vara förebilder, men vara medvetna om att det man går igenom som är dåligt med diskriminering behöver man inte visa för barnen. Man måste kunna hantera den biten själv. Jag tycker att man ska låta barnen hantera det när det kommer.

Den bakomliggande problematiken gällande föräldrars val att antingen berätta om rasismen i samhället och eller avstå påminner om den ökade medvetenheten kring skolgång och rätt skola. Föräldraskap i ett samhälle med diskriminerande och rasistiska strukturer kräver fler medvetna val och strategier som sannolikt aldrig är perfekta utan utgör svåra vägval i en situation som inte kan lösas utan majoritetsbefolkningens medverkan. Sådana svåra val präglar även nästa strategi, som ett flertal av våra informanter använder sig av, att agera förebyggande och inspirerande.

\section{Agera förebilder}

Som vi kan se ovan är att söka sig till trygga och representativa platser viktigt för våra informanter. Insikten om att trygghet inte kan uppnås utan samhällsövergripande förändring gör att flertalet av våra informanter väljer att aktivt agera förebilder för andra svarta, men även för majoritetssamhället för att öka medvetenheten om att den svarta gruppen är likvärdig andra samhällsmedborgare. Ahmed, 32 år, berättar hur han ser på förebilders roll för samhällsförändringen:

Jag skulle önska att det var ett land där man bedöms efter annat än sin hudfärg. Där alla förutsätter att du är svensk och hör hemma tills du själv meddelar att du inte kommer härifrån eller inte kan spräket, att jag och mina barn alltid skulle tilltalas på svenska. Jag tror att för att nå dit så måste det funnas förebilder för den svarta befolkningen. Jag ser mig själv som en sådan förebild, någon som arbetar på en arbetsplats som inte är typisk.

Christopher, 50 år, anser att svarta osynliggörs i media och att det måste få ett slut:

När de skulle intervjua mig för en tidning om diskriminering då sa jag till dem att de måste ha mitt ansikte där, så att alla ser att 
jag är där. Det ska vara slut med osynliggörandet.

En liknande problematik identifieras av Samuel, 16 år, som anser att mediabilden av svarta oftast är negativ:

Om någon ser en svart så tänker de: brottsling. Något kriminellt måste de ha gjort. Det är alltid något, då blir det svårt att övertyga folk om man skall sälja något, att de skall köpa det. Det blir bara svårare, därför tar de inte med svarta i reklam. De har inte ett svart ansikte utåt.

Sandra, 21 år, lägger ett delvis annat perspektiv på fenomenet med förebilder. Hon ifrågasätter huruvida det överhuvudtaget är möjligt eller ens önskvärt med förebilder. Genom att problematisera vad som skulle krävas av samhället för att en person med afrikansk bakgrund med Sandras ord sskulle ha möjligheter att göra det mesta av sitt liv « landar hon i att rollen som förebild nog är en omöjlig position:

Jag vet inte om jag har några förebilder. Min förebild är... jag har ingen specifik förebild, för att alla människor jag känner, jag kan inte bli som dem. Jag kan inte bli en rik svensk kvinna. Jag kan se upp till min mamma för att hon jobbar jättemycket för att det ska bli bättre, men jag vill inte heller bli en kvinna som jobbar för att det ska bli bättre. Jag vill vara en kvinna som har det bra. Jag vill bli en afrikansk kvinna som har möligheter att göra det mesta av mitt liv och möligheter att göra det mesta av mina barns liv, och det gör inte min mamma. För att hon går runt och kämpar och fär huvudvärk, och blir diskriminerad på bussen, sen kommer hon tillbaka igen, och springer runt och diskuterar och pratar med politiker. Man blir trött på det också, ansvaret ska inte ligga på några enstaka individer, att de ska ta på sig ansvaret att hjälpa en hel grupp. Och därför saknar jag förebilder, det blir hopplöst.

Sandra tar fasta på den ambivalens som finns inbyggd $i$ att både agera förebild och sätta sin tilltro till att förebildsrollen är tillräcklig för att skapa förändring. Kampen för gruppens rättigheter är inspirerande och viktig, men samtidigt förblir kämpande individer ett tecken på att rasism och diskriminering inte är utrotade och att samhällsstrukturer hindrar svarta svenskar att bejaka de möjligheter och drömmar de hade valt i en värld utan diskriminering. Förändring sker inte utan konfrontationer, vilket nästa avsnitt tyder på.

\section{Agera konfrontativt}

Den fjärde strategin som vi har kunnat identifiera är av direkt karaktär och indikerar en medvetenhet om att förändring och kamp för ens rättigheter kräver att motsättningar hanteras. Flera av dem vi har intervjuat berättar att de säger ifrån när diskrimineringen sker. Miriam, 28 år, uttrycker det som att hon ständigt "bråkar»:

Jag har inte haft några problem, men jag tror att det beror på att jag har bråkat. Folk orkar inte bråka.

En förälder vi har intervjuat, Eliza, 40 år, berättar om hur hon fått »slåss» tillbaka när 
hennes dotter har behandlats på ett kränkande sätt i skolan:

Då har jag varit aggressiv på ett intelligent sätt. Eftersom jag arbetade i skolans värld, så använde jag deras språk och regler, och satt på otaliga möten och skrev brev. Så att jag har fätt slåss tillbaks, de vågade inte annat än att ge oss rätt. Men det har varit jättejobbigt.

Att behöva bevaka sina rättigheter, som andra kan ta för givna, talar även Mark, 35 år, om. Han berättar om en incident där han i ett utbildningssammanhang felaktigt placerades på den lägsta nivån trots sin kompetens i ämnet. Trots överlägsna studieresultat fick han inte flytta över till den nivå som motsvarade hans kunskaper. Det var först när han i en diskussion med läraren ilsknade till som han fick gehör för sina krav:

Jag frågade henne vad hon menade: att jag är för dum för att läsa nästa nivå? Lät mig göra ett prov? Och då sa hon ok. Jag fick anmäla mig till nivåb. Men det var först när jagblev arg...

Cindy, 39 år, berättar om när hon fick stå på sig i en arbetsintervju och säga ifrån vid en kränkande behandling:

När jag gick på intervju, var det en chef som kom sent, kom in stressad, och vi var 5-6 st. som satt och väntade. Han kom in och frägade mig, är det du som sökt det här jobbet? Varför har du sökt det här jobbet? Hur länge har du bott här? Jag förklarade att jag hade bott här $i 5$ år. Då sa han,' jag tror inte att du har kompetens att jobba här. Vi har de senaste datorerna, har du lärt dig data i ditt hemland?' Jag blev så arg. Jag tycket att det var oförskämt, och kände att även om jag inte får jobbet måste jag säga min mening. Jag sa till honom att man ska inte bara räkna hur många år man bott i Sverige och att han skulle titta på mina kompetenser. Det är så, de tror att man kommer från skogen. De tror att det som de ser på TV är det rätta och när man landar här, börjar man från noll.

Konfrontation som strategi är riskabel, som Cindy antyder, särskilt när den används $i$ utbildnings- och arbetslivssammanhang där negativ särbehandling utövas av en person i auktoritetsposition med mandat att anställa, betygsätta eller på andra sätt påverka den orättvist behandlade personens framtida möjligheter. Riskerna kan också inbegripa hot mot ens fysiska integritet och även ens liv, vilket Paul, 32 år, berättar om för oss:

Jag blev attackerad av nazister. Jag hade otur, det var den 30 november och hade varit och handlat mat och skulle hem. ${ }^{2} \mathrm{Jag}$ såg bara en grupp människor, sen när jag kom närmare såg jag att det var nynazister, och kopplade att det var 30 november. Jag visste direkt att jag inte kunde vika av åt ett

2 Den 30 november samlas nynazistiska grupper för att demonstrera och hylla minnet av Karl XII som stupade den 30 november 1718. Det svenska nationella studentförbundet började ha fackeltåg till minne av Karl XII redan 1853. Efter första världskriget upphörde de men började åter 1921. Då bildade Lunds nationella grupper 30 november-föreningen för att fortsätta med fackeltågen. 
annat håll, för då kommer de att jaga mig. Såatt jag bara gick igenom dem, och det var några som knuffade till mig och sa 'djävla neger'. Det var flera hundra, jag stängde av mig själv.

Pauls konfrontation med nazister utspelar sig så att han inte ger vika och agerar utifrån sin rättighet att gå ner för gatan istället för att försöka undvika dem, eftersom risken för att bli attackerad inte kan minimeras oavsett hans val. Konfrontation som strategi synliggör tydligast vilka svårigheter och vilken ojämlikhet som svarta svenskar utsätts för, särskilt när de agerar i enlighet med sina rättigheter till likabehandling. Kännetecknande för konfrontation som strategi är att personer som agerar diskriminerande tenderar att besitta större resurser jämfört med den som utsätts för diskriminering. Dessa större resurser må bestå av myndighetsutövning i form av betygssättning, chefsposition eller hundratals våldsbenägna extremister; de flesta av dessa positioner är också problematiska för att den negativa särbehandling som utövas troligen inte ifrågasätts av majoritetsbefolkningen i de instanser där konfrontationerna sker. Den utelämnade positionen gör att många av de intervjuade överväger att lämna Sverige för att öka sina chanser att bli behandlade på ett rättvisare sätt.

\section{Lämna Sverige}

Många av de intervjuade överväger att bosätta sig i ett annat land, ett land som de förknippar med större möjligheter att bli bemött som en person och inte som repre- sentant för en nedvärderad grupp. När till exempel Patrick, 16 år, skulle ge uttryck för varför han tror att hans framtid är ljusare i England pekade han på omöjligheten för honom som svart att göra anspråk på svenskheten:

Jag ska flytta till England [...] Där är alla engelsmän, men här är man aldrig svensk.

Eliza, 40 år, önskar en bättre framtid för sin dotter i USA för att upplevelsen av att känna sig hemma är starkare där:

Hon vill t.ex. inte bo $i$ Sverige för att hon känner att hon inte kan känna sig hemma. Hon har många vänner här, och de flesta är vita, men hon känner sig mer 'relaxed' $i$ USA med släktingar där. Jag säger bara till min dotter, åk till USA med min 'blessing'.

Övervägandet att flytta från Sverige eller stödja sina barn när de väljer att göra det baseras på flera kompletterande föreställningar om ökade möjligheter till ett värdigt liv, såsom möjligheten att inneha arbetspositioner som speglar ens utbildning, att betraktas som medborgare och att effektivare kunna kräva att ens rättigheter bevakas är större i länder i Afrika samt i Storbritannien och USA. Önskan att lämna Sverige tyder också på att även om de vardagliga och socioekonomiska konsekvenserna av diskriminering drabbar de svarta svenskarna, berörs även det övriga samhället på lång sikt, genom förlusten av en grupp människor som väljer att bidra till samhällsutvecklingen i de länder där det är mer troligt att de behandlas som fullvärdiga medborgare. 


\section{Diskussion: resultat och bidrag}

Vi ser två huvudsakliga bidrag med vår studie. För det första att vi genom att fokusera på vardagsrasismen skiftar blicken från det spektakulära till det ordinära (Essed 1991). De händelser som sker i vardagen är sällan de som uppmärksammas. För den som utsätts för dem leder de dock till ett samlat vardagslivsmönster av differentiering där upplevelser av kränkning och negativ särbehandling ingår. Vår studie tyder på att svarta svenskar utsätts för en specifik typ av diskriminering, som är särskilt tydlig ifråga om kränkande språkbruk, integritetskränkningar och sexuella trakasserier. Med utgångspunkt i vår teoretiska referensram och diskursen om primitivism, anser vi att svarta svenskar i vår studie ger uttryck för upplevelser av en för den svarta gruppen specifik rasism. Misstänkliggörande och hatbrott inbegriper, som våra intervjupersoner indikerar, för gruppen svarta svenskar specifika rasistiska skällord och utseendediskriminering. Vidare kan institutionella effekter av diskriminering och rasism ha allvarliga följder, inte minst i form av ett kraftigt inskränkt handlingsutrymme. Svårigheter att få komma in på de utbildningar man önskar sig eller få anställning på basis av ens meriter är exempel på det.

Vårt andra bidrag är att vi genom att vi väljer att studera upplevelser av rasism inom en specifik grupp - svarta svenskar nyanserar debatten om diskriminering och den etniska rangordningens yttringar i Sverige. Som vi tidigare har nämnt, finns det för tillfället lite forskning som berör svarta svenskars situation. Vidare anser vi i enlighet med våra teoretiska utgångspunkter att nyanseringen av debatten kring diskriminering kräver att samspel med andra diskrimineringsgrunder, i vårt fall genus, lyfts fram. Vår studie problematiserar dessutom bilden av de diskriminerade som passiva offer genom att deras motståndsstrategier får avsevärt utrymme i artikeln. Våra informanter försöker aktivt bekämpa diskriminerande behandling och skapa bättre förutsättningar för likabehandling åt sig själva, såväl som å sina barns och övriga gruppmedlemmars vägnar. $\AA$ ena sidan har vi strategier såsom strävan efter trygghet och representativitet, å andra sidan har vi de konfrontationer som denna strävan många gånger kan kräva. Det yttersta steget i sökandet efter ett värdigt liv är strategin att lämna Sverige för länder och platser som förknippas med ökade chanser att få delta i samhällslivet på likvärdiga villkor.

Synliggörandet av motståndsstrategier innebär inte att svarta svenskar inte drabbas och påverkas långsiktigt av den negativa särbehandlingen de utsätts för. Tvärtom, som till exempel olika försök att skydda och förebreda barnen för framtiden i Sverige visar, finns det inga entydiga och säkra vägar att följa. Ett liv i ett samhälle med diskriminerande strukturer ställer omöjliga krav på de utsatta individerna; bekämpning av diskrimineringen kan ske framgångsrikt först när samhällsstrukturer synliggör och stödjer den kampen.

Motståndsstrategier och diskrimineringsförebyggande arbete kräver också att forskningen, i en självkritisk anda, förmedlar de diskriminerades röster och berät- 
telser, snarare än att tala för dem. Ett viktigt bidrag i vår studie är således att skapa utrymme för en föga utforskad och synliggjord grupps - svarta svenskars - upplevel- ser, utan att vare sig reducera dem till en enfaldig offerroll eller trivialisera allvaret i de kränkningar de förmedlar i sina berättelser.

\section{Referenser}

Andersson, Roger (2002) "Boendesegregation och etniska hierarkier«. I Magnus Dahlstedt \& Ingemar Lindberg (red.) Det slutna folkhemmet. Om etniska klyftor och blågul självbild. Stockholm: Agora.

Balibar, Etienne \& Wallerstein, Immanuel (2002) Ras, nation, klass: Mångtydiga identiteter. Göteborg: Daidalos.

Blomqvist, Paula Rodrigo (2005) Närvarons politik och det maingetniska Sverige. Om att ta plats $i$ demokratin. Göteborg: Förvaltningshögskolan, Göteborgs Universitet.

Dahlstedt, Magnus \& Lindberg, Ingemar (2002) "Det slutna folkhemmet. Om etniska klyftor och blågul självbild». I Ingemar Lindberg \& Magnus Dahlstedt (red.) Det slutna folkhemmet. Om etniska klyftor och blågul självbild. Stockholm: Agora.

Essed, Philomena (1991) Understanding everyday racism: an interdisciplinary theory. Newbury Park: SAGE.

Lykke, Nina (2005) „Nya perspektiv på intersektionalitet. Problem och möjligheter". Kvinnovetenskaplig tidskrift $\mathrm{nr}$ 2-3, s. 7-18.

Motsieloa, Viveca (2003) "Det måste vara någonting annat«: en studie om barns upplevelser av rasism i vardagen. Stockholm: Rädda Barnen.
Neergaard, Anders (2002) "Arbetsmarknadens mönster - om rasifierad segmentering巛. I Magnus Dahlstedt och Ingemar Lindberg (red.) Det slutna folkhemmet. Om etniska klyftor och blågul självbild. Stockholm: Agora.

Prasad, Pushkala (2005) Crafting qualitative research. Working in the postpositivist traditions. Armonk, New York, London: M.E. Sharpe.

de los Reyes Paulina, Molina Irene \& Mulinari Diana (red.) (2002) Maktens (o) lika förklädnader. Kön, klass \& etnicitet $i$ det postkoloniala Sverige. Stockholm: Atlas.

de los Reyes, Paulina \& Mulinari, Diana (2005) Intersektionalitet. Kritiska reflektioner över (o)jämlikhetens landskap. Malmö: Liber.

SCB (2007) Befolkningsstatistik från Statistiska Centralbyrån.

Schmauch, Ulrika (2006) Den osynliga vardagsrasismens realitet. Umeå: Umeå Universitet, Sociologiska institutionen.

Young, Robert J. C. (1995) Colonial desire: hybridity in theory, culture and race. London, New York: SAGE

Van Dijk, Teun A. (1993) Elite discourse and racism. Newbury Park, London, New Delhi: SAGE. 


\section{Summary}

\section{Handling racism and discrimination as a black Swede}

This article explores discrimination and racism as it is experienced by black Swedes. Our study takes its point of departure in the existing research on ethnic stratification and hierarchy in Sweden and we aim to contribute to this particular research area by highlighting the experiences of everyday racism as well as the coping strategies that black Swedes deploy. Our study is based on 60 interviews with individuals who identify themselves, or are identified by the surrounding society, as black.

Our findings suggest that black Swedes experience five types of specific forms of everyday discrimination and racism. Here we have racialized and demeaning language use, integrity violations, sexual harassment, suspicion of crime, and hate crimes. These five forms of discriminatory treatment can have long-term effects depending on the institutional settings within which they are enacted. Institutions such as workplaces and educational institutions, within which these forms of discrimination frequently occur, can affect black Swedes' possibilities to pursue education or gain employment.

We have also identified five coping strategies black Swedes employ in order to combat discrimination and attempt to create a life of equal opportunities for themselves, their children and their peers. Black Swedes seek representation and security by choosing social networks and geographical areas which allow interaction with other black Swedes. Furthermore, the parenting role for black Swedes entails attempts to protect their children from discrimination by a conscious choice of schools and the dilemma of choosing to talk about racism. Black Swedes commonly attempt to act as role models and engage in confrontations when subjected to discriminatory treatment. One final strategy that many of our interviewees speak of is to leave Sweden in the hope of creating a life of equal opportunities abroad. 